Article

\title{
Microwave-Supported Leaching of Electric Arc Furnace (EAF) Slag by Ammonium Salts
}

\author{
Zhibo Tong ${ }^{1,2} \mathbb{D}^{\mathbb{D}}$, Guojun Ma ${ }^{1, *}$, Xiang Zhang ${ }^{1}$ and Yongsheng Cai ${ }^{1}$ \\ 1 The State Key Laboratory of Refractories and Metallurgy, Wuhan University of Science and Technology, \\ Wuhan 430081, China; tongzhibo0@gmail.com (Z.T.); zx91@wust.edu.cn (X.Z.); \\ caiyongsheng0@gmail.com (Y.C.) \\ 2 The Key Laboratory of Extraordinary Bond Engineering and Advanced Materials Technology, \\ Yangtze Normal University, Chongqing 408100, China \\ * Correspondence: gma@wust.edu.cn
}

Received: 1 June 2017; Accepted: 7 July 2017; Published: 13 July 2017

\begin{abstract}
The effect of microwave-supported leaching of electric arc furnace (EAF) slag by ammonium salts was investigated to improve calcium leaching ratio for $\mathrm{CO}_{2}$ mineral sequestration process. The results show that the calcium leaching ratio from EAF slag at the constant temperature in the microwave field increases about $10 \%$ than that under the water bath at the same leaching time. The greater the microwave power, the higher the impact of calcium leaching rate, which proves that microwave treatment can improve the leaching ratio of calcium. The rapid calcium leaching step (up to $5 \mathrm{~min}$ ) is possibly due to the easy reaction of calcium silicate, while the slower calcium leaching step (after $5 \mathrm{~min}$ ) is owing to the difficult reaction of calcium ferroaluminates for the hydrolysis of iron and aluminum. The leaching behaviors of magnesium and calcium ions affected by different leaching parameters are similar and the concentration of aluminum, iron and phosphorus can be neglected. Calcium ion is probably not precipitated in the real leaching solution from steel slag by ammonium chloride solution as its concentration is less than $0.32 \mathrm{~mol} / \mathrm{L}$. However, the concentration of magnesium ion starts to drop sharply when the $\mathrm{pH}$ value is higher than 10 and it has precipitated completely at $\mathrm{pH}$ value of 11.6 .
\end{abstract}

Keywords: microwave; EAF slag; leaching; ammonium chloride; kinetics

\section{Introduction}

As fossil fuels will still be the main power source in the near future and its combustion would emit significant amounts of greenhouse gases, an economically viable approach to sequestrate $\mathrm{CO}_{2}$ is becoming more and more necessary. Meanwhile, the worldwide production of crude steel has reached $1.63 \times 10^{6} \mathrm{Mt}$ in 2016 [1], large amounts of steel slag generated simultaneously, which are estimated to about 10 15\% by weight of the total produced crude steel [2]. Furthermore, the iron and steel industry is recognized as one of the largest $\mathrm{CO}_{2}$ emission industries with total amounts of 1500 1600 $\mathrm{Mt} \mathrm{CO}_{2}$ emission [3]. Currently, the waste steelmaking slag are mainly used as fluxing agent of iron and steel smelting [4,5], fertilizer of agricultural production [6,7], construction materials (such as slag cement, brick, concrete and construction aggregate) [8], soil conditioner [9], as well as adsorbent of environmental protection [10]. However, for these applications only a small part of the slag can be utilized, especially in China, where the utilization rate of steel slag is only $22 \%$, which is far behind the developed countries [11]. The uses of $\mathrm{CO}_{2}$ in the waste off-gas and unused slag are limited for various causes and difficulties. Therefore, large amounts of slag are stockpiled, which are costly and seriously harmful to the environment, such as damaging soil and vegetation or polluting air and water. 
In 1990, Seifritz proposed a safe and permanent method of $\mathrm{CO}_{2}$ sequestration based on chemically combining $\mathrm{CO}_{2}$ with abundant raw materials to form stable carbonate minerals [12]. It was improved by using waste slag to sequestrate $\mathrm{CO}_{2}$ due to significant levels of calcium, high alkalinity in the slag and in situ $\mathrm{CO}_{2}$ mineral carbonation in iron and steel plants. An approach involving calcium ion leaching from the waste slag with the ammonium salts, and subsequently reacting with $\mathrm{CO}_{2}$ to produce precipitation calcium carbonate (PCC), has been reported recently [13-17]. The usage of ammonium chloride solution as an extraction reagent in the indirect aqueous processes of $\mathrm{CO}_{2}$ sequestration is currently widely investigated for high efficiency and selective extraction of calcium and easy purification process. The process mainly consists of a two-step reaction as follows.

$$
\begin{aligned}
& 2 \mathrm{CaO} \cdot \mathrm{SiO}_{2}(\mathrm{~s})+4 \mathrm{NH}_{4} \mathrm{Cl}(\mathrm{aq}) \rightarrow 2 \mathrm{CaCl}_{2}(\mathrm{aq})+2 \mathrm{H}_{2} \mathrm{O}+\mathrm{SiO}_{2}(\mathrm{~s}) \downarrow+4 \mathrm{NH}_{3}(\mathrm{aq}) \\
& 4 \mathrm{NH}_{3}(\mathrm{aq})+2 \mathrm{CO}_{2}(\mathrm{aq})+2 \mathrm{CaCl}_{2}(\mathrm{aq})+4 \mathrm{H}_{2} \mathrm{O}(\mathrm{l}) \rightarrow 2 \mathrm{CaCO}_{3}(\mathrm{~s}) \downarrow+4 \mathrm{NH}_{4} \mathrm{Cl}(\mathrm{aq})
\end{aligned}
$$

Ammonium chloride is consumed in the first step and regenerated in the second step, thus, the extraction agent can be recycled. Compared with ammonium salts leaching, the $\mathrm{pH}$ of the leached system needs to be improved after leaching for nitric acid and sulfuric acid to make the following carbonation reaction possible, while using acetic acid as a leaching solution would leach large amounts of other elements besides calcium, such as magnesium [18-21]. Therefore, the whole process cost would be reduced by using ammonium chloride as a leaching agent, due to fewer requirements for the $\mathrm{pH}$ adjusting and purification process. However, the calcium extraction efficiency with ammonium salts is much lower than that with acidic extraction. In order to improve the calcium leaching ratio from electric arc furnace (EAF) slag, this paper proposes the methods of assisting the calcium leaching in a microwave field and proves the possibility of improving calcium extraction efficiency from EAF slag, and the optimization of the process was also studied.

\section{Experimental Procedure}

The as-received carbon steel EAF slag was provided by a local steelmaking plant, and the main chemical composition of EAF slag was analyzed with inductively coupled plasma emission spectroscopy (IRIS Advantage ER/S) as $39 \% \mathrm{CaO}, 28 \% \mathrm{Fe}_{2} \mathrm{O}_{3}, 12 \% \mathrm{SiO}_{2}, 8 \% \mathrm{MgO}$ and $4 \% \mathrm{Al}_{2} \mathrm{O}_{3}$, which indicates that it is suitable for mineral $\mathrm{CO}_{2}$ sequestration due to its high basicity $\left(\mathrm{CaO} / \mathrm{SiO}_{2}>2.7\right)$ and calcium content. A batch of $2 \mathrm{~kg}$ EAF slag was crushed in a vibratory disk mill and ground in a planet-type ball mill. The ground slag was subsequently dried in an oven at $110{ }^{\circ} \mathrm{C}$ for $24 \mathrm{~h}$.

In order to compare the calcium extraction efficiency in the microwave leaching process, a first batch of leaching experiments at the constant temperature with water bath and in a microwave field were carried out in a three-necked flask, respectively. In the experiment, the particle size of EAF slag, which is smaller than $54 \mu \mathrm{m}$, was selected. The leaching process was assisted by magnetic stirring at the maximum rate, and the other leaching process parameters were $20 \mathrm{~mL} / \mathrm{g}$ liquid-solid ratio, $200 \mathrm{~mL}$ solution volume and $2 \mathrm{~mol} / \mathrm{L}$ ammonium chloride solution. Moreover, the effect of various leaching parameters (stirring speed, leaching solution volume, liquid-solid ratio, leaching solution concentration) on calcium leaching ratio from EAF slag was also studied on a second experimental batch at fixed temperature $\left(60^{\circ} \mathrm{C}\right)$ under microwave field, on EAF slag particles grinded less than $100 \mu \mathrm{m}$.

In the conventional leaching experiment, the reaction temperature was conducted with water bath and the leachant was stirred magnetically. The microwave chemical reactor MCR-3 can provide two kinds of microwave outputs, i.e., a stable microwave power and a stable temperature with variable microwave heating output. The experiment temperature in the microwave field was monitored with a trifluoroethylene thermocouple. Both conventional and microwave leaching experiments were equipped with a condenser pipe system.

In the microwave leaching process of constant temperature, the leaching solution was heated to the aimed temperature, then the EAF slag was added into the leaching solution and the microwave 
chemical reactor was switched on immediately, while the leaching reaction in the leaching process of constant microwave power begins from room temperature. At a certain time, a part of the reactant was sampled and filtered. The calcium concentrations of leachate were analyzed with the ethylenediaminetetraacetic acid (EDTA) titration method of GB/T 15452-2009 [22]. Moreover, the concentrations of magnesium, aluminum, iron and phosphorus at the final leaching solution were analyzed by inductively coupled plasma emission spectroscopy (IRIS Advantage ER/S, Thermo Jarrell Ash, Franklin, MA, USA). The filtered leached slag residue was washed with Reverse Osmosis water (RO water) three times and dried at $115^{\circ} \mathrm{C}$ for $24 \mathrm{~h}$. The mineralogical phases of the slag residue were determined by an X'Pert PRO MPD X-ray diffractometer with $\mathrm{Cu} \mathrm{K} \alpha$. A field emission scanning electron microscopy (Nova 400 NanoSEM, FEI, Hillsboro, OR, USA) coupled with energy dispersive spectrometer (INCAIE 350 PentaFET X-3 EDS, Oxford, UK) was used to analyse the as-received slag sample and the leached slag residue.

The leaching ratio of calcium ion was calculated by the following equation:

$$
x_{\mathrm{Ca}^{2+}}=\frac{{ }^{c} \mathrm{Ca}^{2+} \times V_{\mathrm{T}}}{m_{\mathrm{slag}} \times \eta_{\mathrm{CaO}} \times \frac{M_{\mathrm{Ca}}}{M_{\mathrm{CaO}}}}
$$

where $x_{\mathrm{Ca}^{2+}}$ is the leaching ratio of calcium; $c_{\mathrm{Ca}^{2+}}$ is the concentration of $\mathrm{Ca}^{2+}$ in the filtrate, $\mu \mathrm{g} / \mathrm{mL}$; $V_{T}$ is the total volume of the leaching solution, $\mathrm{mL} ; m_{\text {slag }}$ is the mass of the EAF slag, $\mathrm{g} ; \eta_{\mathrm{Ca}^{2+}}$ is the content of $\mathrm{CaO}$ in the EAF slag, \%; $M_{\mathrm{Ca}}, M_{\mathrm{CaO}}$ are the molecular mass of $\mathrm{Ca}$ and $\mathrm{CaO}$, respectively.

\section{Results and Discussion}

\subsection{Calcium Leaching by $\mathrm{NH}_{4} \mathrm{Cl}$ with Conventional and Microwave Leaching Processes}

The calcium leaching ratio from the EAF slag by $\mathrm{NH}_{4} \mathrm{Cl}$ under different leaching environments are shown in Figure 1. It can be seen from Figure 1a that the calcium leaching ratio rose significantly at the initial period ( $5 \mathrm{~min}$ ) and then tends to the maximum value, which attains $~ 87 \%$ with $120 \mathrm{~min}$ leaching at $100{ }^{\circ} \mathrm{C}$. Figure $1 \mathrm{~b}$ is the variation of calcium leaching ratio with leaching time at constant temperature in a microwave field. Comparing with Figure 1a,b, the tendencies of the calcium leaching ratios are similar, which attains the maximum leaching ratio within $5 \mathrm{~min}$. However, the calcium leaching ratio at the constant temperature in the microwave field increases about $10 \%$ than that under the water bath at the same time. This is possibly due to the fact that the polar molecules in the leaching system vibrate rapidly in the microwave field, producing a large amount of energy, which heats the solution and increases the collision frequency between the slag materials and solution. Moreover, the fresh surfaces in the slag particles exposed on the crack caused by the microwave are beneficial for the extraction reaction [23-25].

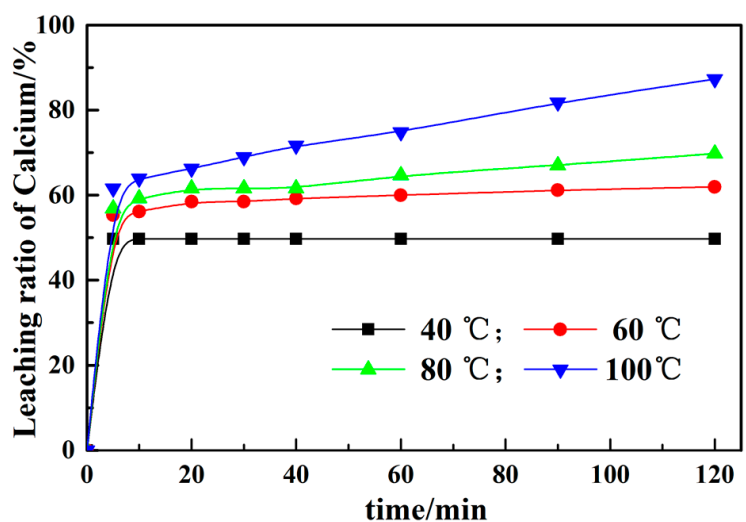

(a)

Figure 1. Cont. 


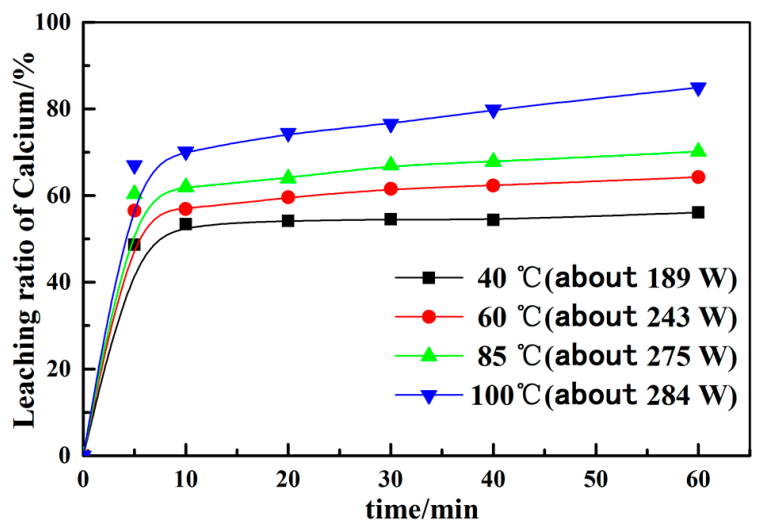

(b)

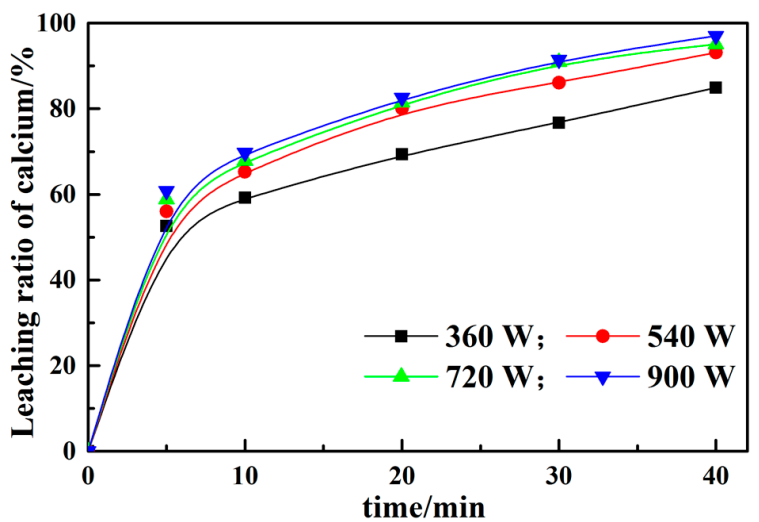

(c)

Figure 1. Calcium leaching ratio from the electric arc furnace (EAF) slag by $\mathrm{NH}_{4} \mathrm{Cl}$ under the different environments: (a) at constant temperature under water bath; (b) at constant temperature in the microwave field; (c) at constant power in the microwave field.

It can be seen from Figure $1 \mathrm{~b}, \mathrm{c}$ that the greater the microwave power, the higher the impact of calcium leaching ratio, which proves that the thermal effect and non-thermal effect generated by the microwave field improve the leaching ratio. Meanwhile, the leaching solutions are boiling within several minutes at constant power in the microwave field. Therefore, the following experiments were further studied at the constant temperature in the microwave field.

XRD analysis of the as-received EAF slag and the leached slag residue after different leaching processes are shown in Figure 2. The crystalline phases of the as-received EAF slag, containing $\mathrm{Ca}(\mathrm{Fe}, \mathrm{Al})_{2} \mathrm{O}_{5}, \mathrm{CaFe}\left(\mathrm{Si}_{2} \mathrm{O}_{6}\right), \mathrm{RO}$ phase, $\mathrm{CaCO}_{3}, \mathrm{CaMgSi}_{2} \mathrm{O}_{6}, \mathrm{CaSiO}_{3}, \mathrm{Ca}_{2} \mathrm{SiO}_{4}$ and $\mathrm{Ca}_{3} \mathrm{SiO}_{5}$, are complex, while the crystalline phases of the leached slag residue at different leaching parameters are similar. Compared with the as-received EAF slag and the leached slag residue, it can be found that $\mathrm{CaSiO}_{3}$, $\mathrm{Ca}_{2} \mathrm{SiO}_{4}$ and $\mathrm{Ca}_{3} \mathrm{SiO}_{5}$ are disappeared and $\mathrm{SiO}_{2}$ is detected after the leaching process, which indicates that $\mathrm{CaSiO}_{3}, \mathrm{Ca}_{2} \mathrm{SiO}_{4}$ and $\mathrm{Ca}_{3} \mathrm{SiO}_{5}$ are dissolved in the ammonium chloride solution and $\mathrm{SiO}_{2}$ is produced. 


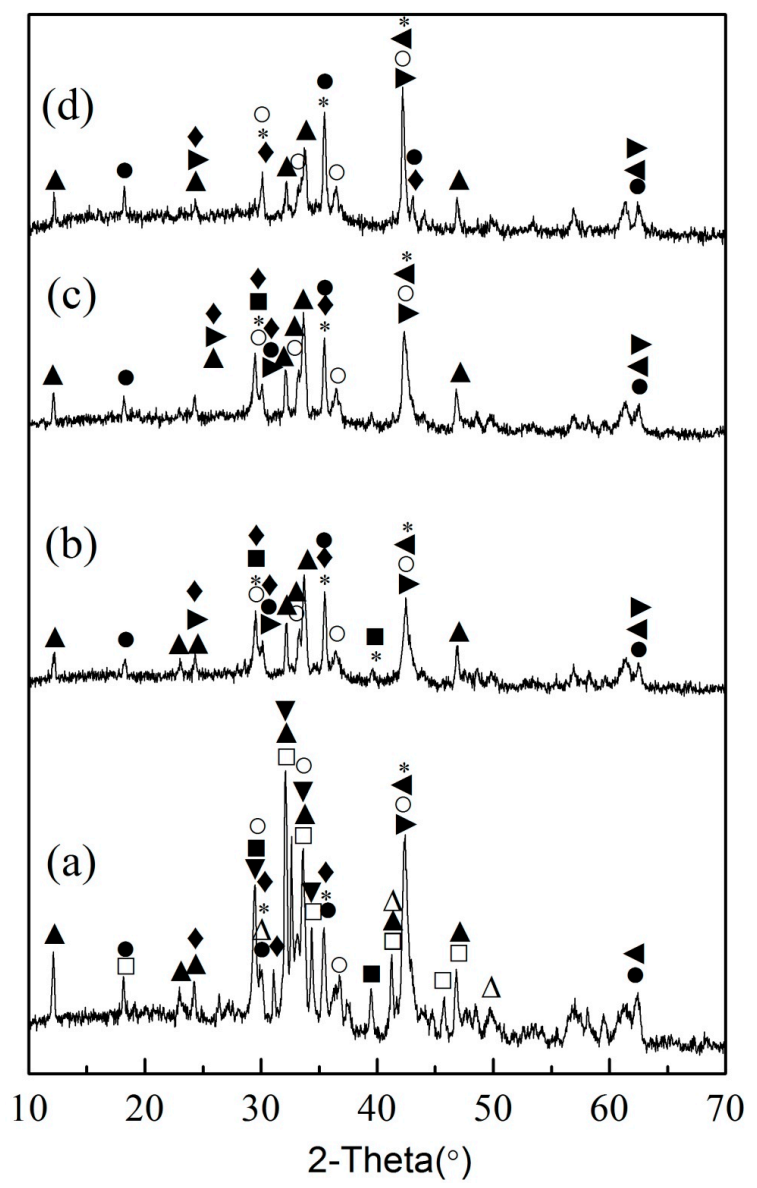

Figure 2. Representative XRD pattern of slag under different process $(\mathrm{Cu} \mathrm{K} \alpha)(\boldsymbol{\Lambda} \mathrm{CaFA}$; $\left.\bigcirc \mathrm{Ca}_{3} \mathrm{Fe}_{2}\left(\mathrm{SiO}_{4}\right)_{3} ;{ }^{*} \mathrm{CaFe}\left(\mathrm{SiO}_{3}\right)_{2} ; \mathrm{CaMgSi}_{2} \mathrm{O}_{6} ; \bullet \mathrm{RO} ; \mathbf{\mathrm { CaCO } _ { 3 }} \triangle \triangle \mathrm{CS} ; \square \mathrm{C}_{2} \mathrm{~S} ; \boldsymbol{\nabla} \mathrm{C}_{3} \mathrm{~S} ; \bullet \mathrm{SiO}_{2} ; \triangleleft \mathrm{MgO}\right)$. (a) as-received EAF slag; (b) leached slag residue without microwave $\left(85^{\circ} \mathrm{C}\right)$; (c) leached slag residue with microwave $\left(85^{\circ} \mathrm{C}\right)$; (d) leached slag residue with microwave $(540 \mathrm{~W})$.

Figures 3 and 4 are the SEM images of as-received EAF slag and the leached slag residue with microwave $\left(85^{\circ} \mathrm{C}\right)$ for $60 \mathrm{~min}$, respectively. Table 1 shows the EDS results of the related compounds. Not only the phases detected in the XRD such as $\mathrm{Ca}_{2} \mathrm{SiO}_{4}, \mathrm{Ca}_{2}(\mathrm{Fe}, \mathrm{Al})_{2} \mathrm{O}_{5}$ and $\mathrm{RO}$ phase in Figure 3, but also the phases undetected in the XRD such as $\mathrm{SiO}_{2}, \mathrm{f}-\mathrm{CaO}$ (free calcium oxide) and metal Fe are observed in the SEM images. This may be due to metallic iron and free lime being below the detection limit of conventional XRD. It can also be seen that the RO phase and calcium-ferrite solid solution often coexist with the calcium silicate [26,27]. Besides containing iron, the RO phase, with poor hydration activity, contains high magnesium. Calcium-ferrite solid solution usually contains aluminum existing as calcium ferroaluminates. In Figure 4, it is found that the particles with high contents of iron mainly contain $\mathrm{RO}$ phase and calcium ferroaluminates. The RO phase contains low calcium element at original phase, while the calcium ferroaluminates contain relatively high calcium element. Given that the calcium ferroaluminates in the slag residue leached by ammonium chloride solution still contain relatively high contents of calcium, it shows that the calcium in the form of calcium ferroaluminates is difficult to extract. Moreover, as the phosphorus is mainly dissolved in $\mathrm{C}_{2} \mathrm{~S}$ and $\mathrm{C}_{3} \mathrm{~S}$ in the steelmaking slag $[28,29]$, the leached slag residue particles containing phosphorus, probably the calcium silicates before leaching, have high levels of silicon and less amounts of iron and calcium, which indicates that most of the calcium has been leached from $C_{2} S$ and $C_{3} S$ phases by ammonium chloride solution. The SEM results are consistent with the XRD analysis. 


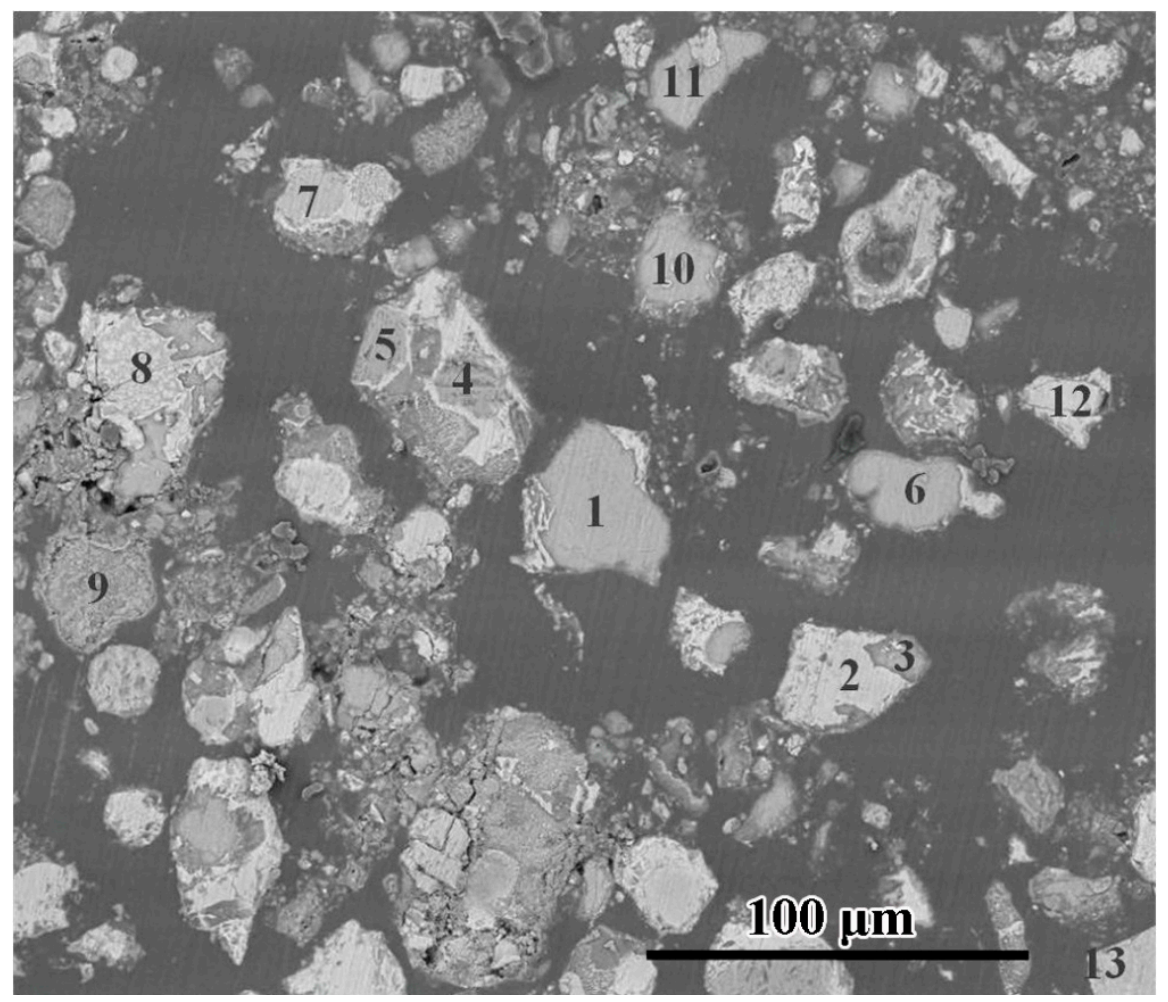

Figure 3. The SEM images of as-received EAF slag.

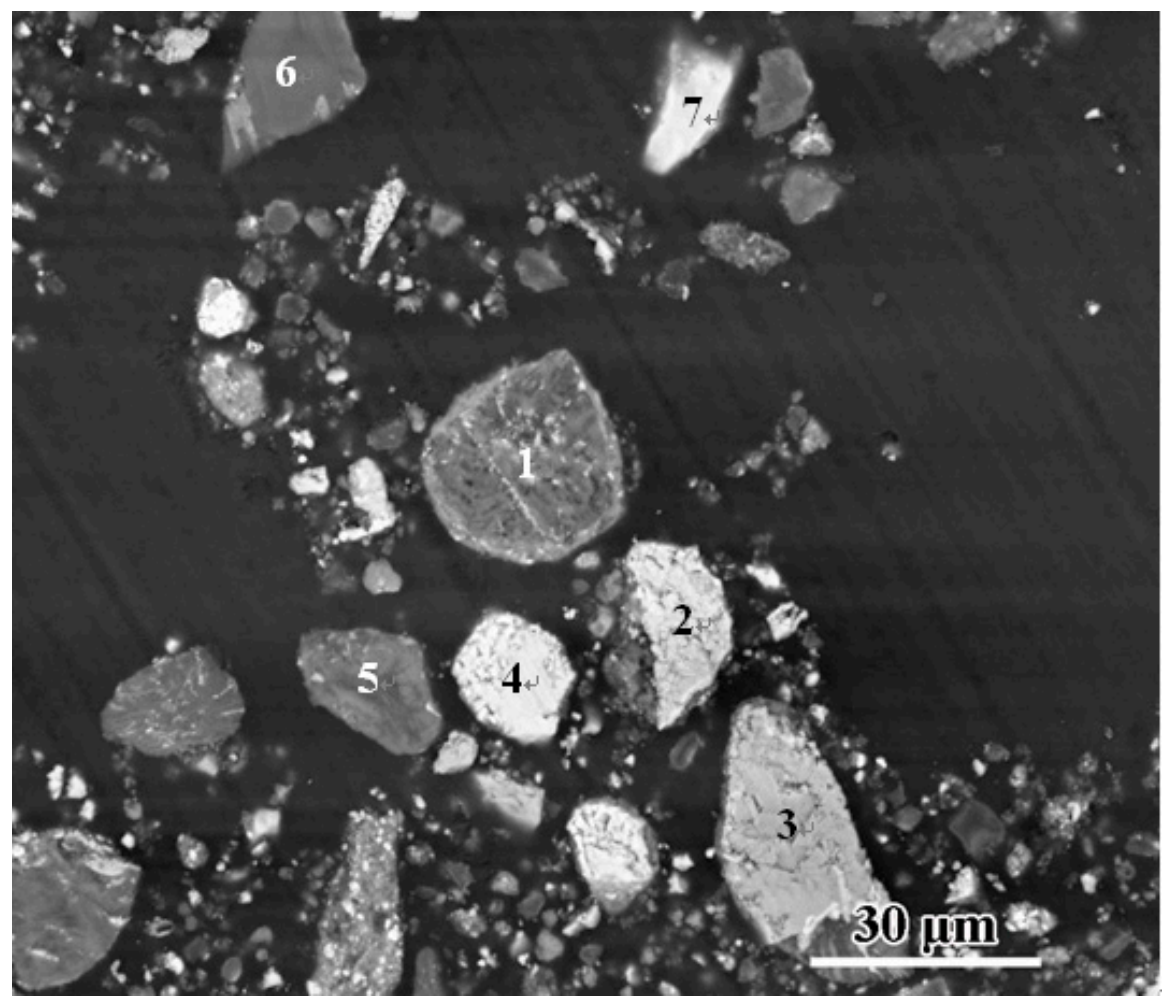

Figure 4. The SEM images of leached slag residue with microwave $\left(85^{\circ} \mathrm{C}\right)$ for $60 \mathrm{~min}$. 
Table 1. The related results of energy dispersive spectrometer (EDS) (Atomic percent) $/ \%$.

\begin{tabular}{|c|c|c|c|c|c|c|c|c|c|}
\hline & Spectrum & $\mathrm{Mg}$ & Al & Si & $\mathbf{P}$ & $\mathrm{Ca}$ & Mn & $\mathrm{Fe}$ & Possible Phase \\
\hline \multirow{13}{*}{ Figure 3} & 1 & & & 33.31 & & 65.3 & & 1.36 & $\mathrm{Ca}_{2} \mathrm{SiO}_{4}(\mathrm{C} / \mathrm{S}=1.96)$ \\
\hline & 2 & 54 & & & & 1.58 & 3.23 & 41.22 & RO phase \\
\hline & 3 & & & 32.54 & & 66.2 & & 1.29 & $\mathrm{Ca}_{2} \mathrm{SiO}_{4}(\mathrm{C} / \mathrm{S}=2.03)$ \\
\hline & 4 & 75.4 & & & & & 1.79 & 22.8 & RO phase \\
\hline & 5 & 76.8 & & & & 0.84 & 2.32 & 20.04 & RO phase \\
\hline & 6 & & & 31.98 & & 68 & & & $\mathrm{Ca}_{2} \mathrm{SiO}_{4}(\mathrm{C} / \mathrm{S}=2.13)$ \\
\hline & 7 & 62.6 & & & & & 2.03 & 35.4 & RO phase \\
\hline & 8 & 59 & & & & & 3.64 & 37.34 & RO phase \\
\hline & 9 & 6.55 & & 5.59 & & 66.9 & 4.34 & 16.66 & - \\
\hline & 10 & & & 32.24 & & 66.3 & & 1.42 & $\mathrm{Ca}_{2} \mathrm{SiO}_{4}(\mathrm{C} / \mathrm{S}=2.07)$ \\
\hline & 11 & & & 31.88 & & 67.2 & & 0.9 & $\mathrm{Ca}_{2} \mathrm{SiO}_{4}(\mathrm{C} / \mathrm{S}=2.11)$ \\
\hline & 12 & & 13.37 & & & 50.5 & & 36.18 & $\mathrm{CaFA}(\mathrm{C} /(\mathrm{A}+\mathrm{F})=1.02)$ \\
\hline & 13 & 59.1 & & & & & 5 & 35.94 & RO phase \\
\hline \multirow{7}{*}{ Figure 4} & 1 & 1.85 & 1.39 & 63.84 & 4.64 & 23.48 & 1.01 & 3.79 & Calcium silicate after leached \\
\hline & 2 & 51.47 & & & & 2.32 & 3.40 & 42.81 & RO phase \\
\hline & 3 & 68.96 & & & & 0.92 & 3.15 & 26.98 & RO phase \\
\hline & 4 & 33.39 & 0.14 & & & 1.25 & 5.28 & 59.94 & RO phase \\
\hline & 5 & 1.12 & 1.90 & 55.37 & 13.43 & 24.99 & & 3.19 & Calcium silicate after leached \\
\hline & 6 & 2.91 & 4.23 & 62.41 & 8.42 & 18.33 & 1.17 & 2.53 & Calcium silicate after leached \\
\hline & 7 & & 9.60 & 1.44 & & 47.54 & & 41.42 & $\mathrm{CaFA}(\mathrm{C} /(\mathrm{A}+\mathrm{F})=0.93)$ \\
\hline
\end{tabular}

Figure 5 is the element mapping of typical leached slag residue with microwave power of $540 \mathrm{~W}$ for $10 \mathrm{~min}$ radiation. It shows that the particles with large amounts of calcium are rich in iron and aluminum, while those particles with less calcium are rich in silicon. Based on the thermodynamics analysis that calcium silicate and calcium ferroaluminates can react with ammonium chloride [30], as well as the fact that iron and aluminum will completely hydrolyze in the system of $\mathrm{NH}_{4} \mathrm{Cl}-\mathrm{NH}_{3}-\mathrm{H}_{2} \mathrm{O}$, it can predict that $\mathrm{CaSiO}_{3}, \mathrm{Ca}_{2} \mathrm{SiO}_{4}$ and $\mathrm{Ca}_{3} \mathrm{SiO}_{5}$ easily react in ammonium chloride solution and the hydrolysis of iron and aluminum on the surface of the particles hinders further calcium leaching from calcium ferroaluminates.
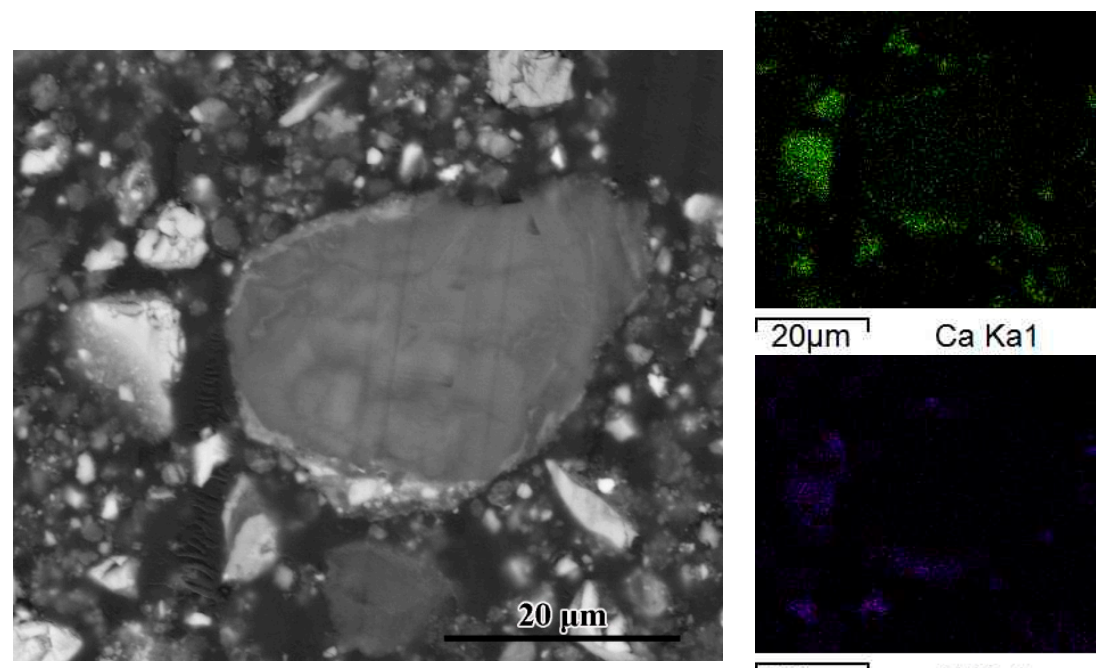

$\sqrt{20 \mu \mathrm{m}} \quad \mathrm{Al} \mathrm{Ka1}$
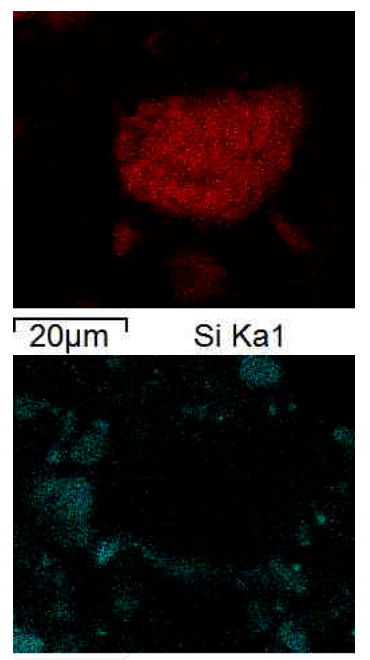

$\sqrt{20 \mu \mathrm{m}}$ Fe Ka1

Figure 5. Element mapping of typical leached slag with $540 \mathrm{~W}$ microwave (10 min).

Since the principal phases of EAF slag are calcium silicate, $\mathrm{RO}$ phase and calcium ferroaluminates, and RO phase contains little calcium; the main calcium sources in the leaching reaction process are calcium silicate and calcium ferroaluminates. From Figure 1, the rapid calcium leaching step (up to $5 \mathrm{~min}$ ) is possibly due to the easy reaction of calcium silicate, and the slower calcium leaching step (after $5 \mathrm{~min}$ ) is owing to the difficult reaction of calcium ferroaluminates for the hydrolysis of iron and aluminum. 


\subsection{Effect of Different Leaching Parameters on Calcium Leaching Ratio from EAF Slag}

Although the leaching rate of calcium increases with the increasing of microwave power, the higher microwave power makes the solution temperature too high, even boiling and resulting in an overflow of ammonia, which goes against the absorption of carbon dioxide and the formation of calcium carbonate in the follow-up carbonate step. Therefore, the following calcium leaching experiments are studied at $60^{\circ} \mathrm{C}$ under microwave fields. Figure 6 is the effect of different process parameters on the calcium leaching behavior. In Figure $6 \mathrm{a}$, calcium leaching ratio increases significantly when the stirring rate is raised from $2 / 4 v_{\mathrm{m}}$ to $3 / 4 v_{\mathrm{m}}\left(v_{\mathrm{m}}\right.$ is the maximum stirring rate of magnetic stirring); however, the leaching ratio does not increase much with the stirring rate increased from $3 / 4 v_{\mathrm{m}}$ to $4 / 4 v_{\mathrm{m}}$. It indicates that the external diffusion is not the restrictive conditions of calcium leaching when the stirring is $3 / 4 v_{\mathrm{m}}$. It is shown in Figure $6 \mathrm{~b}$ that the calcium leaching ratio slightly increases with leaching solution volume decreasing, which may be due to the solution of the mixing intensity being relatively lower under a certain stirring rate when the reaction solution volume increased significantly. In Figure $6 c, d$, the calcium leaching ratio increases with the liquid-solid ratio increasing. Meanwhile, the concentration of calcium in the solution drops rapidly. Therefore, a suitable liquid-solid ratio is required considering the calcium leaching ratio and the concentration of calcium. With the concentration of ammonium chloride solution increasing, the concentration of calcium in the leachate rises (Figure 6e). It is possibly due to the fact that the lower $\mathrm{pH}$ value of the leaching system leaded by the higher concentration of ammonium chloride is favorable for the calcium leaching [2]. However, the excessive concentration of ammonium chloride solution is also not good to avoid impacting the absorption and precipitation of $\mathrm{CO}_{2}$ at the subsequent carbonate process.

As the extraction ratio of calcium in EAF slag is nearly $70 \%$ and reaction ratio of calcium in leaching solution with carbon dioxide almost reaches $100 \%$ [31], $\mathrm{CO}_{2}$ uptakes can be calculated as 306 $\mathrm{g} \mathrm{CO}_{2} / \mathrm{kg}$ slag for the EAF slag containing $39 \%$ calcium oxide, compared to the thin-film condition and slurry-phase route (176 280 $\mathrm{g} \mathrm{CO}_{2} / \mathrm{kg}$ slag) [3].

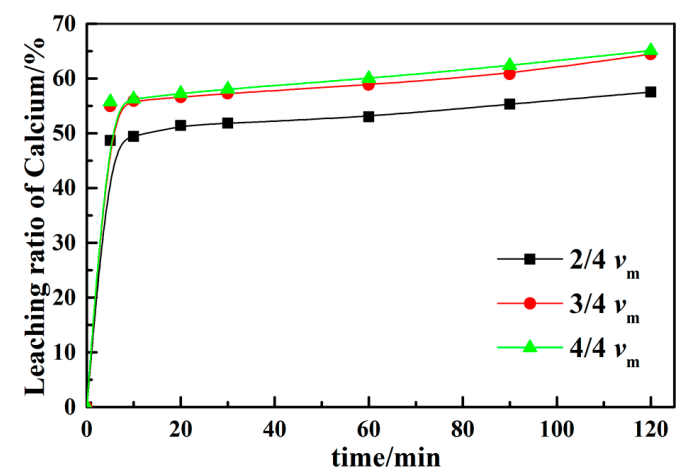

(a)

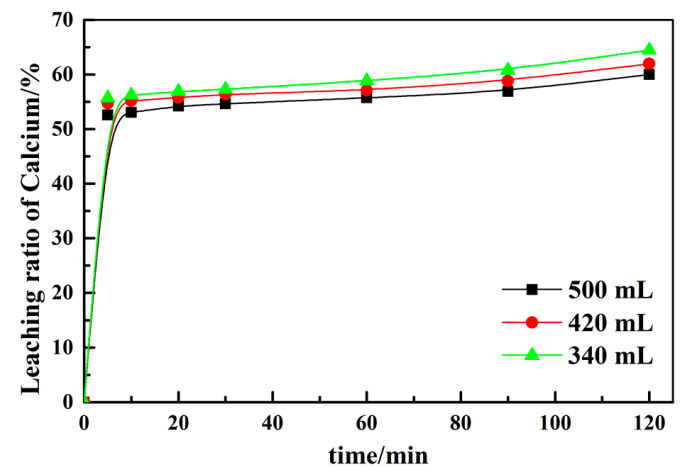

(b)

Figure 6. Cont. 


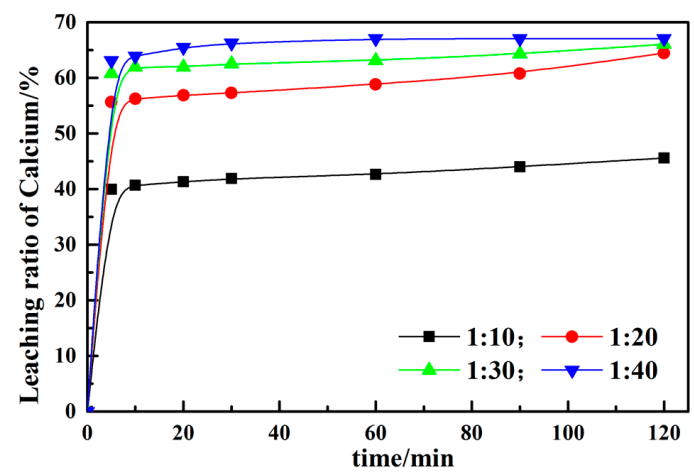

(c)

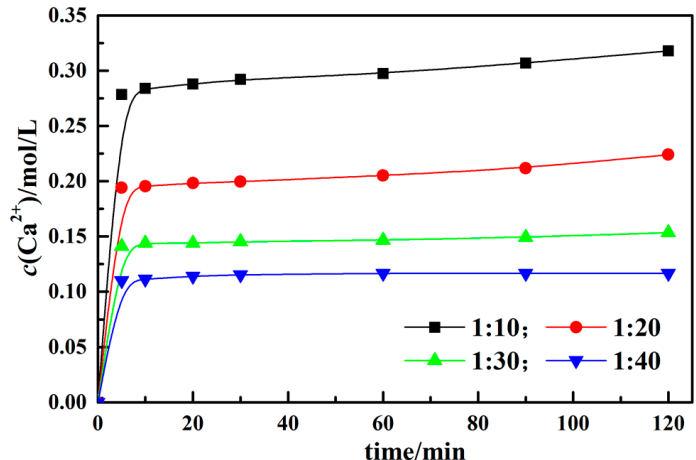

(d)

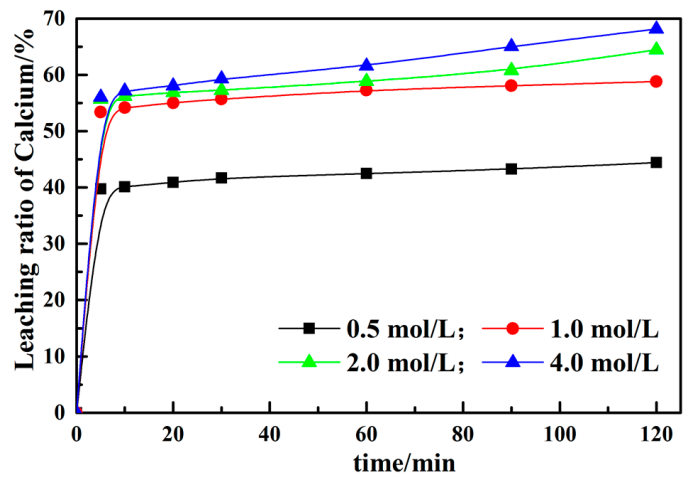

$(\mathbf{e})$

Figure 6. Effect of different technological parameters on calcium leaching: (a) the stirring speeds; (b) the volume of leaching solution; (c,d) the liquid-solid ratio; (e) the leaching solution concentration.

\subsection{Leaching Behaviors of Impurity Ions from EAF Slag}

Figure 7 is the variation of concentration of calcium, magnesium, aluminum, iron and phosphorus ions in the leached solution under different leaching parameters for $120 \mathrm{~min}$. The concentration of aluminum, iron and phosphorus ions are less than $10^{-6} \mathrm{~mol} / \mathrm{L}$, which indicates that it can be neglected. In addition, the leaching behaviors of magnesium and calcium ions are similar. Although the concentration of magnesium is much less than that of calcium, it may be necessary to remove magnesium ion before the carbonate process [32,33]. 


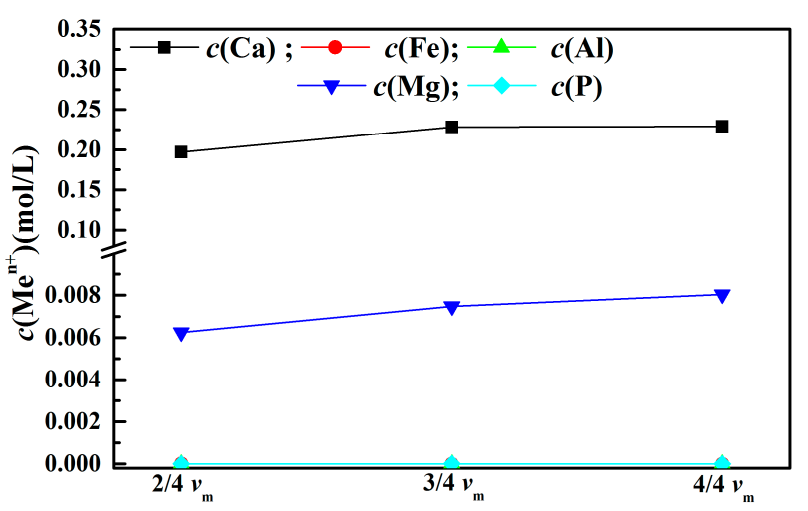

(a)

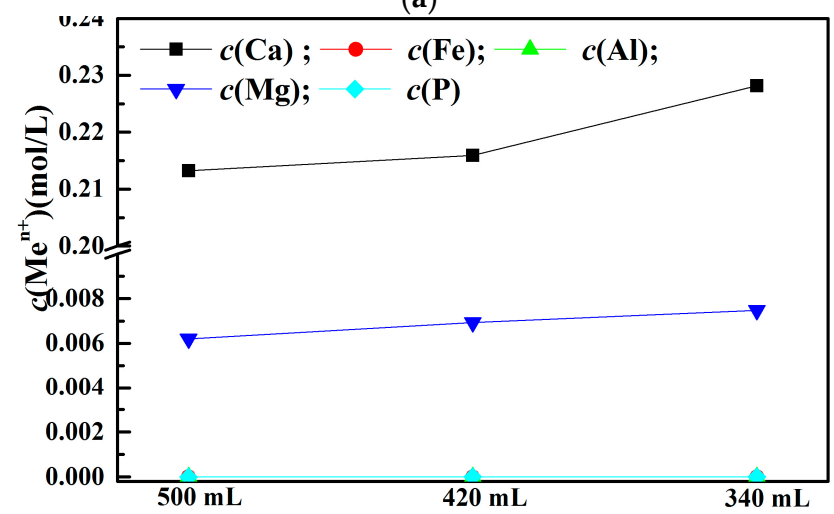

(b)

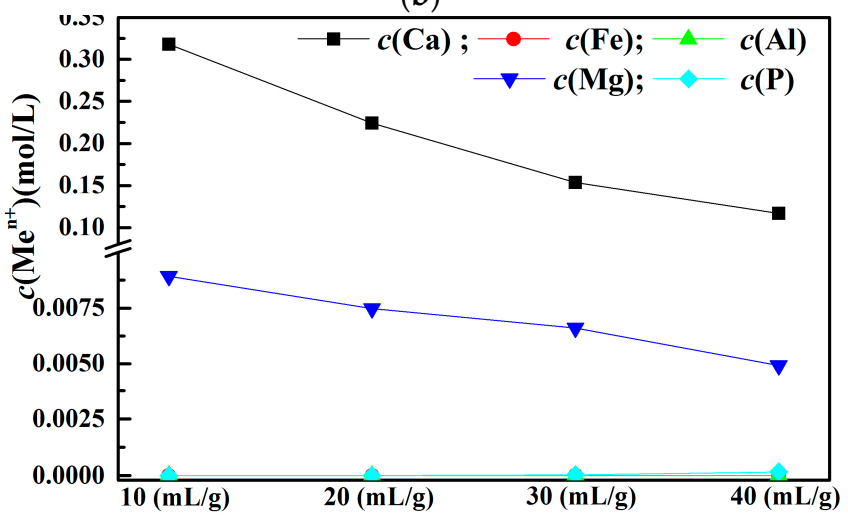

(c)

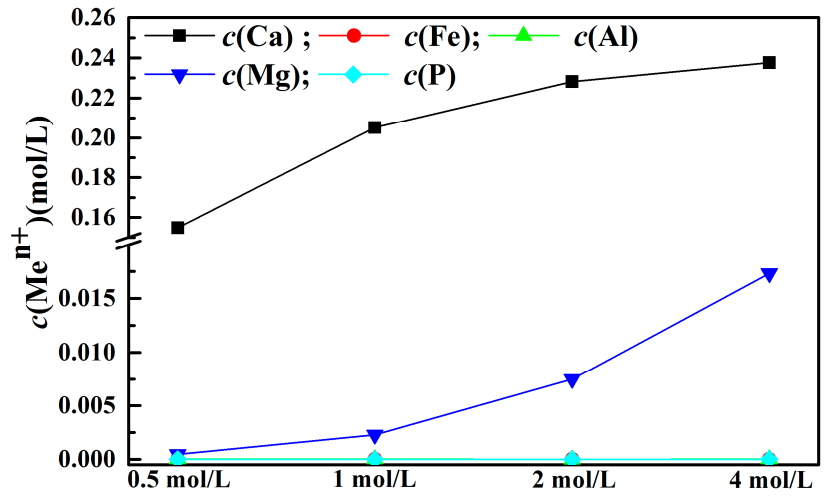

(d)

Figure 7. Effect of different experimental parameters on $\mathrm{Me}^{\mathrm{n}+}$ leaching: (a) the stirring speeds; (b) the volume of leaching solution; (c) the liquid-solid ratio; (d) the leaching solution concentration. 


\subsection{Removal of Impurity Ions from the Leachate}

As the concentrations of aluminum, iron and phosphorus ions can be neglected, and magnesium ion is the major impurity in the leached solution, the removal of magnesium ion by adjusting $\mathrm{pH}$ value was studied. A $500 \mathrm{~mL}$ experimental solution was set up containing $0.5 \mathrm{~mol} / \mathrm{L} \mathrm{CaCl}_{2}, 0.2 \mathrm{~mol} / \mathrm{L}$ $\mathrm{MgCl}_{2}, 1 \mathrm{~mol} / \mathrm{L} \mathrm{NH}_{3} \cdot \mathrm{H}_{2} \mathrm{O}$ and $2 \mathrm{~mol} / \mathrm{L} \mathrm{NH}_{4} \mathrm{Cl}$, and then the configured solution was shaken up and left standing for $24 \mathrm{~h}$, after which the configured solution was filtered, and the filtrate was selected as the solution for the removal experiment of magnesium ion by adding $15 \mathrm{~mol} / \mathrm{L}$ sodium hydroxide solution.

In Figure 8, it can be seen that the required volume of sodium hydroxide solution to raise the $\mathrm{pH}$ value of the solution reduces gradually, which is due to the buffering effect caused by the system of $\mathrm{NH}_{4} \mathrm{Cl}-\mathrm{NH}_{4}-\mathrm{H}_{2} \mathrm{O}$. In addition, the concentration of calcium in the solution, $0.32 \mathrm{~mol} / \mathrm{L}$ when the $\mathrm{pH}$ value is 11.6, is still high, which indicates that the calcium ion is probably not precipitated in the real leaching solution from steel slag by $\mathrm{NH}_{4} \mathrm{Cl}$ solution as the calcium concentration of the real solution is less than $0.32 \mathrm{~mol} / \mathrm{L}$ (Figure 7). This is important to obtain high carbonation efficiency, since only dissolved $\mathrm{Ca}$ can be used for $\mathrm{CO}_{2}$ sequestration. Indeed, Ca precipitation negatively affects $\mathrm{CO}_{2}$ uptake. For this reason, is important to allow only $\mathrm{Mg}$ precipitation, maintaining $\mathrm{Ca}$ ions in the solution. However, the concentration of magnesium ion starts to drop sharply when the $\mathrm{pH}$ value is higher than 10 and it has precipitated completely at $\mathrm{pH}$ value of 11.6. This is due to the solubility of calcium being much bigger than that of magnesium.

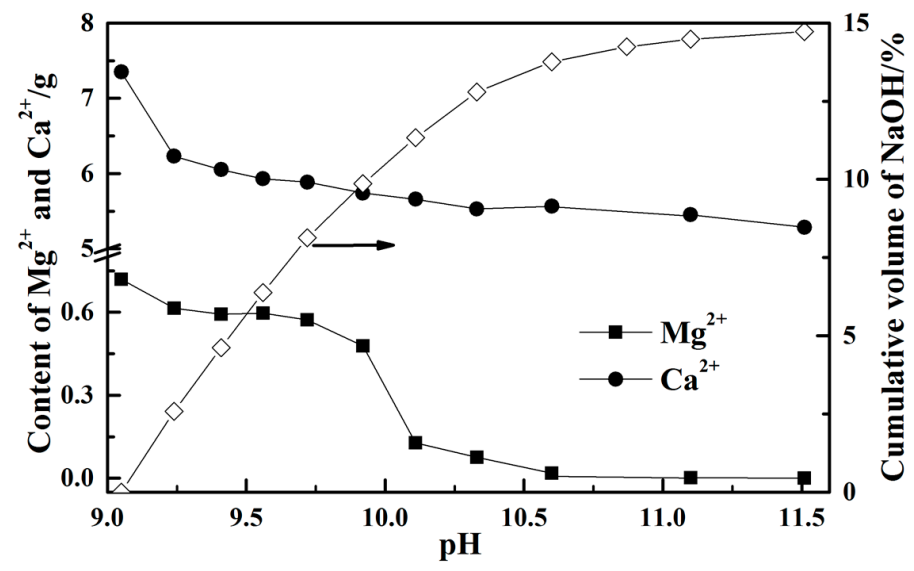

Figure 8. The added volume of $\mathrm{NaOH}$ and the content of $\mathrm{Mg}^{2+} / \mathrm{Ca}^{2+}$ versus $\mathrm{pH}$.

\section{Conclusions}

(1) The calcium leaching ratio at the constant temperature in the microwave field increases about $10 \%$ than that under the water bath at the same time. The greater the microwave power, the higher the impact of calcium leaching ratio, which proves that microwave treatment can improve the leaching ratio. Meanwhile, the leaching solutions are boiling within several minutes at constant power in the microwave field.

(2) The rapid calcium leaching step (up to $5 \mathrm{~min}$ ) is possibly due to the easy reaction of calcium silicate and the slower calcium leaching step (after $5 \mathrm{~min}$ ) is owing to the difficult reaction of calcium ferroaluminates for the hydrolysis of iron and aluminum.

(3) The leaching behaviors of magnesium and calcium ions affected by different leaching parameters are similar and the concentration of aluminum, iron and phosphorus can be neglected.

(4) Calcium ion is probably not precipitated in the real leaching solution from steel slag by $\mathrm{NH}_{4} \mathrm{Cl}$ solution as its concentration is less than $0.32 \mathrm{~mol} / \mathrm{L}$. However, the concentration of magnesium ion starts to drop sharply when the $\mathrm{pH}$ value is higher than 10 and it has precipitated completely at $\mathrm{pH}$ value of 11.6. 
Acknowledgments: The authors gratefully acknowledge the National Natural Science Foundation of China (51374161).

Author Contributions: Zhibo Tong contributed to the experimental data and analysis presented in this manuscript; Guojun Ma contributed to the conception of the study and discussion on the experimental results; Xiang Zhang and Yongsheng Cai helped review this manuscript.

Conflicts of Interest: The authors declare no conflict of interest.

\section{References}

1. Edwin, B. World Steel in Figures 2017; World Steel Association: Brussels, Belgium, 2017.

2. Baciocchi, R.; Costa, G.; Polettini, A.; Pomi, R. Effects of thin-film accelerated carbonation on steel slag leaching. J. Hazard. Mater. 2015, 286, 369-378. [CrossRef] [PubMed]

3. Baciocchi, R.; Costa, G.; Di Gianfilippo, M.; Polettini, A.; Pomi, R.; Stramazzo, A. Thin-film versus slurry-phase carbonation of steel slag: $\mathrm{CO}_{2}$ uptake and effects on mineralogy. J. Hazard. Mater. 2015, 283, 302-313. [CrossRef] [PubMed]

4. Topkaya, Y.; Sevinç, N.; Günaydın, A. Slag treatment at kardemir integrated iron and steel works. Int. J. Miner. Process. 2004, 74, 31-39. [CrossRef]

5. Tong, Z.B.; Ma, G.J.; Cai, X.; Xue, Z.L.; Wang, W.; Zhang, X. Characterization and valorization of kanbara reactor desulfurization Waste Slag of Hot Metal Pretreatment. Waste Biomass Valoriz. 2016, 7, 1-8. [CrossRef]

6. Wang, W.; Sardans, J.; Lai, D.; Wang, C.; Zeng, C.; Tong, C.; Liang, Y.; Peñuelas, J. Effects of steel slag application on greenhouse gas emissions and crop yield over multiple growing seasons in a subtropical paddy field in China. Field Crops Res. 2015, 171, 146-156. [CrossRef]

7. Wang, X.; Cai, Q.-S. Steel slag as an iron fertilizer for corn growth and soil improvement in a pot experiment. Pedosphere 2006, 16, 519-524. [CrossRef]

8. Huang, X.; Wang, Z.; Liu, Y.; Hu, W.; Ni, W. On the use of blast furnace slag and steel slag in the preparation of green artificial reef concrete. Constr. Build. Mater. 2016, 112, 241-246. [CrossRef]

9. Das, B.; Prakash, S.; Reddy, P.; Misra, V. An overview of utilization of slag and sludge from steel industries. Resour. Conserv. Recycl. 2007, 50, 40-57. [CrossRef]

10. Kang, H.; An, K.; Kim, D. Utilization of steel slag as an adsorbent of ionic lead in wastewater. J. Environ. SCI Health 2004, 39, 3015-3028. [CrossRef]

11. Yi, H.; Chen, H. An overview of utilization of steel slag. Int. Conf. Waste Manag. Technol. Chin. Soc. Environ. Sci. 2012, 16, 791-801. [CrossRef]

12. Seifritz, W. $\mathrm{CO}_{2}$ disposal by means of silicates. Nature 1990, 345, 486. [CrossRef]

13. Teir, S.; Eloneva, S.; Fogelholm, C.; Zevenhoven, R. Dissolution of steelmaking slags in acetic acid for precipitated calcium carbonate production. Energy 2007, 32, 528-539. [CrossRef]

14. Hall, C.; Large, D.; Adderley, B.; West, H. Calcium leaching from waste steelmaking slag: Significance of leachate chemistry and effects on slag grain mineralogy. Miner. Eng. 2014, 65, 156-162. [CrossRef]

15. Sun, Y.; Yao, M.; Zhang, J.; Yang, G. Indirect $\mathrm{CO}_{2}$ mineral sequestration by steelmaking slag with $\mathrm{NH}_{4} \mathrm{Cl}$ as leaching solution. Chem. Eng. J. 2011, 173, 437-445. [CrossRef]

16. Kodama, S.; Nishimoto, T.; Yamamoto, N.; Yogo, K.; Yamada, K. Development of a new pH-swing $\mathrm{CO}_{2}$ mineralization process with a recyclable reaction solution. Energy 2008, 33, 776-784. [CrossRef]

17. Fagerlund, J.; Nduagu, E.; Romão, I.; Zevenhoven, R. $\mathrm{CO}_{2}$ fixation using magnesium silicate minerals part 1: Process description and performance. Energy 2012, 41, 184-191. [CrossRef]

18. Doucet, F. Effective $\mathrm{CO}_{2}$-specific sequestration capacity of steel slags and variability in their leaching behaviour in view of industrial mineral carbonation. Miner. Eng. 2010, 23, 262-269. [CrossRef]

19. Eloneva, S.; Teir, S.; Salminen, J.; Fogelholm, C.; Zevenhoven, R. Fixation of $\mathrm{CO}_{2}$ by carbonating calcium derived from blast furnace slag. Energy 2008, 33, 1461-1467. [CrossRef]

20. Chiang, Y.; Santos, R.; Elsen, J.; Meesschaert, B.; Martens, J.A.; Gerven, T. Towards zero-waste mineral carbon sequestration via two-way valorization of ironmaking slag. Chem. Eng. J. 2014, 249, 260-269. [CrossRef]

21. Kakizawa, M.; Yamasaki, A.; Yanagisawa, Y. A new $\mathrm{CO}_{2}$ disposal process via artificial weathering of calcium silicate accelerated by acetic acid. Energy 2001, 26, 341-354. [CrossRef]

22. CN-GB. GB/T 15452-2009 Industrial Circulating Cooling Water-Determination of Calcium and Magnesium-EDTA Titration Method; Standardization Administration of China: Beijing, China, 2009. 
23. Al-Harahsheh, M.; Kingman, S. Microwave-assisted leaching-A review. Hydrometallurgy 2004, 73, $189-203$. [CrossRef]

24. Bayca, S. Microwave radiation leaching of colemanite in sulfuric acid solutions. Sep. Purif. Technol. 2013, 105, 24-32. [CrossRef]

25. Madakkaruppan, V.; Pius, A.; Sreenivas, T.; Giri, N.; Sarbajna, C. Influence of microwaves on the leaching kinetics of uraninite from a low grade ore in dilute sulfuric acid. J. Hazard. Mater. 2016, 313, 9-17. [CrossRef] [PubMed]

26. Wang, Y.; Ye, G. A study of the mineral phases of oxygen converter slag and their cementious properties. J. Chin. Ceram. Soc. 1981, 9, 302-308.

27. Dong, O.; Yuping, X.; Junyuan, H. Composition, mineral morphology and cementitious properties of converter slag. J. Chin. Ceram. Soc. 1991, 19, 488-494.

28. Wu, X.; Wang, P.; Li, L.; Wu, Z.; Chen, R. Distribution and enrichment of phosphorus in solidified BOF steelmaking slag. Ironmak. Steelmak. 2013, 38, 185-188. [CrossRef]

29. Li, G.H.; Wu, B.; Zhang, Y.B.; Zhang, K.C.; Chen, Y.L.; Jiang, T. Mineralogical characteristics and comprehensive utilization of converter steel slag. J. Cent. South Univ. 2010, 41, 2065-2071.

30. Zhang, X.; Ma, G.J.; Tong, Z.B.; Xue, Z.L. Microwave-assisted selective leaching behavior of calcium from Basic Oxygen Furnace (BOF) slag with ammonium chloride solution. J. Min. Metall. B. 2017, 2, 139-146. [CrossRef]

31. Tong, Z.B. Basic research of microwave strengthening calcium leaching from EAF steelmaking slag by ammonium salts and its fixation of carbon dioxide. Wuhan Univ. Sci. Technol. 2017, in press.

32. Lackner, K.S.; Wendt, C.H.; Butt, D.P.; Joyce, E.L., Jr.; Sharp, D.H. Carbon dioxide disposal in carbonate minerals. Energy 1995, 20, 1153-1170. [CrossRef]

33. Alamdari, A.; Alamdari, A.; Mowla, D. Kinetics of calcium carbonate precipitation through $\mathrm{CO}_{2}$ absorption from flue gas into distiller waste of soda ash plant. J. Ind. Eng. Chem. 2014, 20, 3480-3486. [CrossRef]

(c) 2017 by the authors. Licensee MDPI, Basel, Switzerland. This article is an open access article distributed under the terms and conditions of the Creative Commons Attribution (CC BY) license (http://creativecommons.org/licenses/by/4.0/). 